Ben J.P. Crul

Laura M. Blok

Jan van Egmond

Robert T.M. van Dongen

\section{The present role of percutaneous cervical cordotomy for the treatment of cancer pain}

Received: 16 November 2004

Accepted in revised form: 9 December 2004

Published online: 25 January 2005

Presented at the 4th Congress of the European Federation of IASP-chapters, September 2003, Prague, Czech Republic.

\section{B.J.P. Crul (两)}

The Pain Centre,

Department of Anaesthesiology,

Radboud University Medical Center Nijmegen, P.O.B. 9101, NL-6500 HB Nijmegen,

The Netherlands

e-mail: b.crul@anes.umcn.nl

Tel.: +31-24-3619032

Fax: +31-24-3613585

B.J.P. Crul • L.M. Blok • J. van Egmond

R.T.M. van Dongen

The Pain Centre,

Department of Anaesthesiology,

University Medical Center Nijmegen,

NL-6500 HB Nijmegen, The Netherlands

\begin{abstract}
The results obtained by percutaneous cervical cordotomy (PCC) were analysed in 43 terminally ill cancer patients treated in our institution from 1998 to 2001. We wished to determine whether there is still a place for PCC in the actual clinical situation with its wide choice of pain therapies. All patients had severe unilateral pain due to cancer, resistant to opioids and co-analgesics. Following PCC, mean pain intensity was reduced from Numeric Rating Scale (NRS) 7.2 to 1.1. At the end of life, pain had increased to NRS 2.9. Initially following PCC a good result $(\mathrm{NRS}<3)$ was obtained in $95 \%$ of patients. At the end of life, a good result was still present in $69 \%$ of patients. Mean duration of survival after the intervention was 118 days
\end{abstract}

(2-1460). In general, complications were mild and mostly subsided within 3-4 days. There was one case of partial paresis of the ipsilateral leg. PCC remains a valuable treatment in patients with treatment-resistant cancer pain and still deserves a place in the treatment of terminal cancer patients with severe unilateral neuropathic or incidence pain.

Key words Percutaneous cordotomy $\cdot$ Cancer pain

\section{Introduction}

Notwithstanding the great progress made in the treatment of cancer pain, not all patients can be treated satisfactorily. In particular, neuropathic pain and incidence pain as encountered in nervous compression or pathological bone fracture can be notoriously difficult to control. Basically, pain treatment in these cases consists of a combination of analgesics according to the WHO-ladder and co-anal- gesics. When this approach is insufficient, continuous subcutaneous, intravenous or spinal infusion techniques can be applied in addition. Nevertheless, some patients fail to respond to these therapies and continue to be dissatisfied.

When in these cases pain is localised, predominantly unilaterally, the application of percutaneous cervical cordotomy (PCC) can be a valuable additional measure. In case of midline or bilateral pain, continuous spinal infusion techniques are preferred for further pain control [1]. 
PCC was introduced in 1965 by Mullan and Rosomoff for the treatment of unilateral intractable cancer pain. PCC consists of a percutaneously applied interruption of the spinothalamic tract in the spinal cord at the spinal level CI-II [2]. Until the mid-1980s the method was frequently applied and was considered as a major tool in the treatment of severe cancer pain, but its popularity decreased considerably due to the availability of oral and transdermal analgesic therapy. Following the introduction of continuous spinal infusion techniques, a further decline occurred in the number of patients treated [3]. This article tries to answer the question whether there is still a place for PCC within the wide array of the actual therapeutic possibilities by analysing the results obtained in our institution with 43 terminally ill cancer patients suffering from intractable unilateral pain and submitted to PCC. All these patients had full access to anticancer therapies and current analgesic measures.

\section{Patients and methods}

In a retrospective study the records of all patients $(n=43)$ who underwent a PCC during the period 1998-2001 in our institution, were analysed (see Table 1). Approval was obtained from the hospital ethical commission.

Registered were demographics, primary tumour, Karnofsky performance status scale (Karnofsky Index rating from 0 to 100 , $0=$ dead, $100=$ no complaints), sites of pain, type of pain, duration of pain prior to PCC, the duration of treatment in our institution prior to PCC, intake of opioids before and following PCC and before death, Numeric Rating Scores (NRS, $0=$ no pain, 10=pain as bad as imaginable) before and after PCC and before death, duration of effect, side effects and complications. Treatment consisted of a multimodal therapeutic approach including medical, psychosocial and spiritual aspects.

Before PCC, patients were treated according to the WHOladder. Opioids were titrated to the level for obtaining satisfactory pain relief or the occurrence of unacceptable side effects.

Table 1 Demographic data $(n=43$, male $=32)$

\begin{tabular}{lcccc}
\hline & Median & Range & Mean & SD \\
\hline Age, years & 59.30 & $29.3-85.8$ & 59.20 & 12.81 \\
$\begin{array}{l}\text { Duration of } \\
\text { symptoms, months }\end{array}$ & 6.00 & $0.3-31.0$ & 8.00 & 6.75 \\
$\begin{array}{l}\text { Duration of } \\
\text { treatment, months }\end{array}$ & 1.50 & $0.1-20.0$ & 3.38 & 4.86 \\
& & & & \\
Karnofsky index, mean & 60.00 & $30.0-90.0$ & 60.20 & 16.00 \\
\hline
\end{tabular}

The majority of patients (30/43) suffered from neuropathic pain insufficiently relieved by a combination of tricyclic antidepressants and anticonvulsants. Incidence pain or pain on movement was present in 23/43 patients.

Previous to PCC, continuous spinal infusion techniques were applied in 7 patients. Two patients received an epidural infusion and 5 patients intrathecal infusions with a combination of morphine and bupivacaine.

Patients were offered the possibility of PCC when they suffered from unilateral pain below the spinal segment $\mathrm{C} 5$, not responding to maximal symptomatic therapy as mentioned above.

Contraindications were blood coagulation disorders, severely reduced ventilatory functions $\left(\mathrm{FEV}_{1}<12 \mathrm{ml} / \mathrm{kg} \mathrm{BW}\right)$ and presumed inability of the patient to cooperate during the procedure.

PCC was carried out by using a two-needle technique. Under direct lateral vision by use of a C-arm image intensifier, a 22 gauge spinal needle is inserted at the level $\mathrm{C} 1-\mathrm{C} 2$ to reach the anterior part of the intrathecal space. Once the needle is inside the intrathecal space, a contrast dye (Lipiodol Ultrafluide, Guerbet Laboratoires, 93600 Aulnay-sur-Blois, France) is injected and three lines become visible: the most anterior line shows the delineation of the anterior border of the spinal cord, the second line represents the dentate ligament and finally the third line is the projection of the posterior dura mater. The spinothalamic tract is positioned just anterior to the dentate ligament. Now a 20 -gauge needle allowing the introduction of a Levin thermocouple electrode is aimed just anterior to the dentate ligament, the position of the spinothalamic (pain) tract (Radionics, Burlington, MA, USA). After introduction of the tip of the electrode into the spinal cord, stimulation is performed using currents with frequencies of $2 \mathrm{~Hz}$ and $50 \mathrm{~Hz}$. Stimulation with $2 \mathrm{~Hz}$ generally provokes contractions of the longus colli musculature at $0.5-1 \mathrm{~V}$. Any other contractions are an indication that the tip of the electrode is in the corticospinal (motor) tract. A lesion here would provoke a paresis of the interested muscles. Repositioning of the needle more anteriorly is needed. Sensory tracts are identified by $50 \mathrm{~Hz}$ stimulation. When the tip of the electrode is inside the spinothalamic tract, intensities of $0.1-0.3$ $\mathrm{V}$ can provoke temperature sensations (warmth or cold) in the corresponding part of the contralateral body half. After meticulous assessment of the correct position of the electrode tip by repeated stimulation, a radiofrequency lesion is made resulting in a tip temperature of $90^{\circ} \mathrm{C}$ for $10 \mathrm{~s}$. Directly following the lesioning, pinprick tests are performed to assess the eventual occurrence of an eventual analgesic area. The technique is described extensively elsewhere [4].

When appropriate, remifentanil was administered intravenously for the reduction of apprehension and stress or to make a recumbent position of the patient possible. A starting dose of remifentanil 3-4 $\mu \mathrm{g} / \mathrm{kg} \mathrm{BW}$ in $4-5$ min was given followed by a continuous intravenous infusion of remifentanil $0.2-0.3 \mu \mathrm{g} / \mathrm{kg}$ $\mathrm{BW} / \mathrm{min}$

If needed, a continuous intravenous infusion of propofol 2-4 $\mu \mathrm{g} / \mathrm{kg} \mathrm{BW} / \mathrm{min}$ was added. Oxygen was added by a nasal catheter 1-2 1/min. Monitoring consisted of EKG and pulse oximetry. Care was taken to ensure that patients were still able to communicate verbally during the whole procedure. The mean duration of PCC was approximately $40 \mathrm{~min}$. 


\section{Results}

Table 2 gives an overview of all patients with diagnosis, pain type, intake of opioids before PCC and after PCC and NRS rating before PCC, after PCC, and before death. Two patients died within one week following PCC. Death was not directly related to PCC.
Directly following PCC, $41 / 43$ patients reported a good result (NRS $\leq 4)$. During follow up until death, 34/40 patients in our series submitted to PCC obtained good pain control (NRS $\leq 4)$ (Tables 3 and 4).

In four patients (patient numbers 6, 21, 33 and 42), PCC had to be repeated within one month due to incomplete blockade. In three patients this was successful. The

Table 2 Overview of patients

\begin{tabular}{|c|c|c|c|c|c|c|c|c|c|c|c|c|c|c|}
\hline Number & $\begin{array}{l}\text { Age at } \\
\text { cord. } \\
\text { (years) }\end{array}$ & Diagnosis & Pain type & $\begin{array}{l}\text { Localisation } \\
\text { of pain }\end{array}$ & $\begin{array}{l}\text { Karnofsky } \\
\text { index }{ }^{\S}\end{array}$ & $\begin{array}{l}\text { Opioids } \\
\text { before }\end{array}$ & $\begin{array}{l}\text { Opioids } \\
\text { after }\end{array}$ & $\begin{array}{l}\text { NRS }^{\#} \\
\text { before }\end{array}$ & $\begin{array}{l}\text { NRS } \\
\text { after }\end{array}$ & $\begin{array}{l}\text { NRS } \\
\text { last }\end{array}$ & Survival & $\begin{array}{l}\text { Spinal } \\
\text { inf. pre } \\
\text { PCC }\end{array}$ & $\begin{array}{l}\text { Spinal } \\
\text { inf. post } \\
\text { PCC }\end{array}$ & Remarks \\
\hline 1 & 71.7 & Mesothelioma & $\mathrm{CS}, \mathrm{IN}$ & R flank & 50 & 400 & 120 & 8 & 2 & 4 & 46 & & & \\
\hline 2 & 66.7 & Mesothelioma & $\mathrm{CV}, \mathrm{CN}$ & L flank & 80 & 300 & 0 & 7 & 0 & 1 & 114 & & & \\
\hline 3 & 64.0 & Mesothelioma & $\mathrm{CN}$ & $\mathrm{R}$ chest & 80 & 420 & 120 & 5 & 0 & & 347 & & & \\
\hline 4 & 75.0 & Mesothelioma & CS, IN & $\begin{array}{l}\text { L chest, } \\
\text { sternum }\end{array}$ & 70 & 492 & 720 & 8.5 & 0 & 2 & 94 & & & $\begin{array}{l}\text { Mirror } \\
\text { pain }\end{array}$ \\
\hline 5 & 74.7 & $\begin{array}{l}\text { Bronchial } \\
\text { carcinoma }\end{array}$ & $\mathrm{CS}$ & $\begin{array}{l}\text { R flank, } \\
\text { shoulder }\end{array}$ & 60 & 30 & 0 & 8 & 2 & & 110 & & & $\begin{array}{l}\text { Weakness } \\
\text { L leg }\end{array}$ \\
\hline 6 & 61.4 & $\begin{array}{l}\text { Bronchial } \\
\text { carcinoma }\end{array}$ & IV & $\mathrm{R}$ chest & 90 & 60 & 60 & 8 & 0 & 0 & 363 & & PCC & \\
\hline 7 & 50.5 & $\begin{array}{l}\text { Bronchial } \\
\text { carcinoma }\end{array}$ & $\mathrm{CN}$ & $\begin{array}{l}\text { L chest, } \\
\text { back }\end{array}$ & 50 & 90 & 90 & 7 & 0 & 4 & 36 & & & \\
\hline 8 & 57.8 & $\begin{array}{l}\text { Bronchial } \\
\text { carcinoma }\end{array}$ & $\mathrm{CN}$ & $\mathrm{L}$ chest & 30 & 720 & 240 & 6 & 0 & 0 & 6 & IT & & \\
\hline 9 & 76.6 & $\begin{array}{l}\text { Bronchial } \\
\text { carcinoma }\end{array}$ & $\mathrm{CN}$ & $\begin{array}{l}\mathrm{L} \text { arm, } \\
\text { chest }\end{array}$ & 70 & 150 & 0 & 9 & 0 & 0 & 40 & & & \\
\hline 10 & 48.5 & $\begin{array}{l}\text { Bronchial } \\
\text { carcinoma }\end{array}$ & $\mathrm{CS}$ & $\begin{array}{l}\mathrm{R} \text { afilla, } \\
\mathrm{L} \text { chest }\end{array}$ & 60 & 600 & 360 & 6 & 4 & 4 & 19 & & & \\
\hline 11 & 70.5 & $\begin{array}{l}\text { Bronchial } \\
\text { carcinoma }\end{array}$ & IS & L shoulder & 60 & 75 & 0 & 7.5 & 0 & 6 & 214 & $\begin{array}{l}\text { Epidural } \\
\text { Epidural }\end{array}$ & & \\
\hline 12 & 36.0 & $\begin{array}{l}\text { Bronchial } \\
\text { carcinoma }\end{array}$ & $\mathrm{CV}$ & $\mathrm{R}$ romp & 70 & 150 & 90 & 8.5 & 6 & 3 & 99 & & & $\begin{array}{l}\text { Weakness } \\
\text { L leg }\end{array}$ \\
\hline 13 & 59.1 & $\begin{array}{l}\text { Bronchial } \\
\text { carcinoma }\end{array}$ & $\mathrm{CS}$ & $\begin{array}{l}\text { L chest, } \\
\text { R leg }\end{array}$ & 30 & 600 & 30 & 8 & 0 & 0 & 6 & & & \\
\hline 14 & 54.7 & $\begin{array}{l}\text { Bronchial } \\
\text { carcinoma }\end{array}$ & $\mathrm{CN}$ & $\mathrm{R}$ pelvis & 60 & 90 & 0 & 8 & 0 & 0 & 3 & & & \\
\hline 15 & 66.2 & $\begin{array}{l}\text { Bronchial } \\
\text { carcinoma }\end{array}$ & CS, IN & $\begin{array}{l}\text { L shoulder, } \\
\text { arm }\end{array}$ & 70 & 440 & 110 & 7 & 0 & 2 & 83 & & & $\begin{array}{l}\text { Mirror } \\
\text { pain }\end{array}$ \\
\hline 16 & 53.0 & $\begin{array}{l}\text { Breast } \\
\text { carcinoma }\end{array}$ & $\mathrm{CS}, \mathrm{IN}$ & $\begin{array}{l}\mathrm{L}, \mathrm{R} \text { chest, } \\
\mathrm{L} \text { groin }\end{array}$ & 30 & 380 & 15 & 8 & 3 & 7 & 68 & & & $\begin{array}{l}\text { Mirror } \\
\text { pain }\end{array}$ \\
\hline 17 & 41.9 & $\begin{array}{l}\text { Malignant } \\
\text { thymoma }\end{array}$ & $\mathrm{CV}$ & $\begin{array}{l}\text { R chest, } \\
\text { groin }\end{array}$ & 60 & 200 & 120 & 5.5 & 0 & 4 & 1381 & IT & IT & $\begin{array}{l}\text { Brief } \\
\text { apnoea, } \\
\text { mirror } \\
\text { pain }\end{array}$ \\
\hline 18 & 66.8 & $\begin{array}{l}\text { Carcinomatous } \\
\text { pleurisy }\end{array}$ & IN & $\begin{array}{l}\text { L chest, } \\
\text { shoulder }\end{array}$ & 60 & 225 & 0 & 5 & 2 & 2 & 417 & & & \\
\hline 19 & 59.3 & $\begin{array}{l}\text { Rectal } \\
\text { carcinoma }\end{array}$ & $\mathrm{CN}, \mathrm{IN}$ & $\begin{array}{l}\mathrm{L} \text { arm, } \\
\text { back }\end{array}$ & 60 & 22.5 & 22.5 & 10 & 2 & 1 & 14 & & & $\begin{array}{l}\text { Weakness } \\
\mathrm{R} \text { leg }\end{array}$ \\
\hline 20 & 71.5 & $\begin{array}{l}\text { Rectal } \\
\text { carcinoma }\end{array}$ & $\mathrm{CN}$ & $\begin{array}{l}\text { Rectum, } \\
\text { R leg }\end{array}$ & 70 & 120 & 90 & 4 & 0 & 2 & 106 & & & \\
\hline 21 & 68.3 & $\begin{array}{l}\text { Colon } \\
\text { carcinoma }\end{array}$ & $\mathrm{CN}$ & $\begin{array}{l}\mathrm{R} \text { leg, } \\
\text { groin }\end{array}$ & 70 & 110 & 0 & 9 & 2 & 3 & 307 & & $\mathrm{PCC}$ & \\
\hline 22 & 50.1 & $\begin{array}{l}\text { Colon } \\
\text { carcinoma }\end{array}$ & IN & $\begin{array}{l}\text { L upper } \\
\text { leg }\end{array}$ & 50 & 450 & 0 & 5 & 1 & 3 & 421 & IT & PCC & \\
\hline 23 & 69.5 & $\begin{array}{l}\text { Colon } \\
\text { carcinoma }\end{array}$ & $\mathrm{CN}$ & $\mathrm{R}$ abdomen & 40 & 90 & 60 & 8 & 0 & 1 & 82 & & IT & \\
\hline
\end{tabular}


Cont. Table 2

\begin{tabular}{|c|c|c|c|c|c|c|c|c|c|c|c|c|c|c|}
\hline Number & $\begin{array}{l}\text { Age at } \\
\text { cord. } \\
\text { (years) }\end{array}$ & Diagnosis & Pain type & $\begin{array}{l}\text { Localisation } \\
\text { of pain }\end{array}$ & $\begin{array}{l}\text { Karnofsky } \\
\text { index }{ }^{\S}\end{array}$ & $\begin{array}{l}\text { Opioids } \\
\text { before }\end{array}$ & $\begin{array}{l}\text { Opioids } \\
\text { after }\end{array}$ & $\begin{array}{l}\mathrm{NRS}^{\#} \\
\text { before }\end{array}$ & $\begin{array}{l}\text { NRS } \\
\text { after }\end{array}$ & $\begin{array}{l}\text { NRS } \\
\text { last }\end{array}$ & Survival & $\begin{array}{l}\text { Spinal } \\
\text { inf. pre } \\
\text { PCC }\end{array}$ & $\begin{array}{l}\text { Spinal } \\
\text { inf. post } \\
\text { PCC }\end{array}$ & Remarks \\
\hline 24 & 54.0 & $\begin{array}{l}\text { Colon } \\
\text { carcinoma }\end{array}$ & $\mathrm{CN}$ & $\begin{array}{l}\text { L leg, } \\
\text { sacrum }\end{array}$ & 80 & 120 & 0 & 7 & 0 & 4 & 298 & & IT & \\
\hline 25 & 82.7 & $\begin{array}{l}\text { Colon } \\
\text { carcinoma }\end{array}$ & CS & $\begin{array}{l}\text { L flank, } \\
\text { ribs }\end{array}$ & 70 & 440 & 120 & 9 & 0 & 4.5 & 255 & & & \\
\hline 27 & 85.8 & $\begin{array}{l}\text { Prostate } \\
\text { carcinoma }\end{array}$ & $\mathrm{CN}$ & L sacrum & 30 & 0 & 0 & 7 & 1 & 4 & 61 & IT & & \\
\hline 28 & 61.6 & $\begin{array}{l}\text { Prostate } \\
\text { carcinoma }\end{array}$ & $\mathrm{CV}, \mathrm{IN}$ & $\begin{array}{l}\text { L leg, } \\
\text { shoulder }\end{array}$ & 50 & 90 & 30 & 8 & 0 & & 191 & & & \\
\hline 29 & 66.7 & $\begin{array}{l}\text { Bladder } \\
\text { carcinoma }\end{array}$ & IN & $\mathrm{L}$ groin & 70 & 60 & 24 & 9 & 3 & 2 & 18 & & & \\
\hline 31 & 54.4 & $\begin{array}{l}\text { Endometrial } \\
\text { carcinoma }\end{array}$ & IS & $\begin{array}{l}\text { L leg, } \\
\text { flank }\end{array}$ & 40 & 135 & 90 & 9 & 0 & 1 & 130 & & IT & $\begin{array}{l}\text { Opioid } \\
\text { withdrawal }\end{array}$ \\
\hline 32 & 60.6 & $\begin{array}{l}\text { Penile } \\
\text { carcinoma }\end{array}$ & $\mathrm{CN}$ & $\begin{array}{l}\text { L chest, } \\
\text { upper leg }\end{array}$ & 60 & 90 & 0 & 5 & 0 & 0 & 22 & & & $\begin{array}{l}\text { Weakness } \\
\mathrm{R} \text { arm }\end{array}$ \\
\hline 33 & 63.6 & Melanoma & $\mathrm{CS}, \mathrm{IN}$ & $\begin{array}{l}\mathrm{L} \text { leg, } \\
\text { groin }\end{array}$ & 60 & 240 & 120 & 6 & 0 & 6 & 108 & & IT, PCC & \\
\hline 34 & 53.0 & Melanoma & IN & $\begin{array}{l}\text { L leg, } \\
\text { arm, back }\end{array}$ & 80 & 210 & 60 & 7 & 0 & & 39 & & & \\
\hline 35 & 29.3 & Melanoma & $\mathrm{CS}, \mathrm{IN}$ & $\begin{array}{l}\text { L knee, } \\
\text { flank }\end{array}$ & 60 & 127 & 90 & 7 & 2 & 1 & 111 & & & $\begin{array}{l}\text { Weakness } \\
\text { R leg }\end{array}$ \\
\hline 36 & 55.7 & Plasmocytoma & $\mathrm{CN}, \mathrm{IN}$ & $\begin{array}{l}\text { R flank, } \\
\text { chest }\end{array}$ & 90 & 270 & 60 & 3 & 0 & 7 & 151 & & & $\begin{array}{l}\text { Mirror } \\
\text { pain }\end{array}$ \\
\hline 37 & 50.0 & $\begin{array}{l}\text { Nasopharyngeal } \\
\text { carcinoma }\end{array}$ & IN & $\mathrm{R}$ chest & 50 & 412.5 & 412.5 & 7 & 4 & 1 & 41 & IT & $\begin{array}{l}\text { IT, } \\
\text { PCC }\end{array}$ & $\begin{array}{l}\text { Mirror } \\
\text { pain }\end{array}$ \\
\hline 39 & 36.7 & Chondrosarcoma & IS, CN & R leg & 40 & 60 & 0 & 8 & 4 & 0 & 454 & & PCC & \\
\hline 40 & 57.5 & Adenocarcinoma ${ }^{\star}$ & $\mathrm{CV}$ & $\mathrm{R}$ flank & 90 & 240 & 60 & 8 & 0 & 2 & 68 & & & \\
\hline 41 & 50.5 & Adenocarcinoma ${ }^{\star}$ & $\mathrm{CS}$ & R leg & 70 & 200 & 200 & 6 & 0 & 3 & 27 & & & $\begin{array}{l}\text { Bladder } \\
\text { dysfunction }\end{array}$ \\
\hline 42 & 46.2 & Adenocarcinoma $a^{\star}$ & $\mathrm{CS}, \mathrm{IN}$ & $\begin{array}{l}\text { R hip, } \\
\text { leg }\end{array}$ & 60 & 180 & 180 & 4 & 2 & 9 & 177 & & PCC & \\
\hline 43 & 58.3 & $\begin{array}{l}\text { Hepatic } \\
\text { carcinoma }\end{array}$ & IV & $\begin{array}{l}\text { L ribs, } \\
\text { head }\end{array}$ & 60 & 190 & 120 & 8 & 2 & 5 & 24 & Epidural & & \\
\hline
\end{tabular}

$\S$ Karnofsky index $(100=$ no complaints, $0=$ dead $)$

\#NRS ( $0=$ no pain, $10=$ pain as bad as imaginable)

*Unknown localisation primary tumour

$C$, continuous; $I$, Incidence pain; $S$, somatic; $V$, visceral; $N$, neuropathic; $R$, right; $L$, left; morphine, morphine equivalents in milligrams; survival, survival in days after PCC; epidural, continuous epidural infusion; IT, continuous intrathecal infusion

Table 3 Mean and median NRS scores

\begin{tabular}{lrrrr}
\hline Results & Median & Range & Mean & SD \\
\hline NRS before PCC & 8 & $3-10$ & 7.19 & 1.6 \\
NRS after PCC & 0 & $0-6$ & 1.10 & 1.7 \\
Reduction $p=0.0001$ & 6 & $2-9$ & 6.09 & 2.1 \\
NRS final & 2 & $0-9$ & 2.90 & 2.5 \\
Reduction $p=0.0001$ & 5 & $-5-9$ & 4.30 & 3.3 \\
Survival, days & 83 & $3-1381$ & 153.00 & 230.0 \\
\hline
\end{tabular}

Table 4 Opioid use in morphine equivalents in milligrams

\begin{tabular}{lrrrr}
\hline Results & Median & Range & Mean & SD \\
\hline Before PCC & 190 & $0-935$ & 252.2 & 209.0 \\
After PCC & 60 & $0-935$ & 125.1 & 194.2 \\
Reduction $p=0.0001$ & 75 & $-228-570$ & 127.1 & 157.4 \\
\hline
\end{tabular}


Table 5 Complications (n)

\begin{tabular}{ll}
\hline Mirror pain & 7 \\
Muscle weakness & 2 \\
Short lasting apnoea & 1 \\
Bladder dysfunction & 1 \\
\hline
\end{tabular}

other patient (patient number 33) was treated with continuous intrathecal infusion with morphine and bupivacaine. Pain relief remained problematic until death. In three patients (patient numbers 22, 37 and 39), PCC was carried out bilaterally with good results and no complications.

The interval between the two interventions was at least 2 weeks.

Previous to PCC in five patients (numbers 8, 17, 22, 27 and 37 ) pain was treated by continuous intrathecal infusion with inadequate results. In two patients (number 17 and 37) the infusion was continued following PCC. Following PCC, five other patients (numbers 17, 23, 24, 30 and 31) were treated with additional continuous intrathecal infusion.

\section{Complications}

One patient had a permanent partial loss of muscle power in his ipsilateral lower limb. All other complications were transient and had minimal impact on the well-being of the patient (Table 5).

\section{Discussion}

This study underlines the fact that PPC can be a valuable additional therapy for the control of severe unilateral cancer pain below the C5 level not amenable to other therapeutic measures, even when treated with continuous spinal infusion of opioids and local anaesthetics. Although complications are mostly transient, the possibility of a permanent lesion cannot be ruled out, as one patient in our series shows. In his case, at electrical stimulation the spinothalamic tract appeared to be localised very closely to the corticospinal motor tract. Inadvertently, interruption of the spinothalamic tract by a radiofrequency lesion here resulted in partial damage of the corticospinal tract.

Pain in patients with advanced aggressive cancer can pose a formidable challenge to the physician. The prevalence of a mixture of somatic, visceral and neuropathic pain types necessitates a tailored and individualised pain therapy [5]. Treatment of patients with complicated pain syndromes requires a multimodal therapeutic approach including causal and symptomatic aspects. Symptomatic therapy also includes supportive measures, paying close attention to the psychosocial and spiritual needs of the patient and her/his relatives.

Drug treatment for cancer pain is still the mainstay of the symptomatic therapy. Studies show that the application of the WHO guidelines and co-analgesics results in good pain relief in $80 \%$ of patients [5]. In the remaining $20 \%$, oral drug therapy does not provide adequate pain relief.

When the predominant pain is located unilaterally in such cases, PCC can be a good option.

PCC is not a panacea, but in selected cases its effect is paramount for achieving acceptable pain relief.

It should be emphasised that prior to PCC all our patients were in severe pain, irresolvable with the current analgesic therapy they had received so far. PCC was judged to be a last resort to achieve control of pain.

The use of sedation still allowing communication between the patient and the doctor during PCC is judged to be an important step forward. The administration of remifentanil creates a certain "emotional detachment" for the patient and results in far better acceptance of the procedure. When the patient experiences relief and comfort this circumstance creates a quiet and relaxed atmosphere in the operating theatre. Before using this type of sedation, patients were often anxious and sometimes in severe distress. This situation was worsened when maintenance of the recumbent position for longer periods became problematic.

In all patients suffering from an aggressive form of cancer, various pain sites were present, located on bilateral locations of the body. Therefore in virtually all cases non-opioids such as acetaminophen and NSAIDs were continued following successful PCC. As opioids can contribute to the patients' sense of well-being, dosages were only gradually tapered and in most cases opioids were continued until death. The use of antidepressants and anticonvulsants was stopped following the control of neuropathic pain.

Despite PCC, it was sometimes necessary to continue intrathecal infusion or to start a continuous intrathecal infusion. It is our firm impression that without the availability of PCC all the patients of this series would have suffered from severe pain (NRS 7 and up) until death, finally requesting sedation.

The complication rate in our series was low and is in accordance with reports in the literature [6-8].

Mirror pain was the most often encountered but could be adequately treated with analgesics. The PCC procedure is technically not simple and requires considerable skills of the physician performing the procedure. Only meticulous attention to detail can prevent the occurrence of neurological complications. Especially the interpretation of 
neurological signs followed by precise repositioning of the electrode requires a broad experience. Not with standing these precautions, a permanent partial loss of motor power can present, as our series demonstrates. To preserve one's professional expertise it is necessary to execute the procedure on a regular basis. Given the fact that PCC is only indicated in a small proportion of cancer patients, execution of PCC therefore should be restricted to a lim- ited number of centres that can act as referral centres. Based on our experience in The Netherlands, one centre for a population of three million seems to be reasonable.

It is concluded that PCC represents an efficacious method of pain reduction in situations in which all other pain therapies fail. Therefore it still deserves a place in present cancer pain management.

\section{References}

1. Van Dongen RTM, Crul BJP, De Bock M (1993) Long-term intrathecal infusion of morphine/bupivacaine mixtures in the treatment of cancer pain: analysis of 51 cases. Pain 55:119-123

2. Mullan S, Hekmatpah J, Dobben G (1965) Percutaneous intramedullary cordotomy utilizing the unipolar anodal electric lesion. J Neurosurg 22:548-553

3. De Conno F, Foley K (1995) Cancer pain relief. Kluwer Academic Publishers, Dordrecht, Boston, London
4. Crul BJP, Van Kleef ME (2003)

Radiofrequency lesions. In: Breivik H, Campbell W, Eccleston C (eds) Clinical pain management, practical applications and procedures. Arnold, London, pp 327-340

5. Sanders M, Zuurmond W (1995) Safety of unilateral and bilateral percutaneous cervical cordotomy in 80 terminally ill cancer patients. J Clin Oncol 13:1509-1512
6. Arnér S, Arnér B (1985) Differential effects of epidural morphine in the treatment of cancer related pain. Acta Anaesthesiol Scand 29:32-36

7. Zech DFJ, Grond S, Lynch J, Hertel D, Lehmann KA (1995) Validation of World Health Organization Guidelines for cancer pain relief: a 10-year prospective study. Pain 63:65-76

8. Nagaro T, Amakawa K, Kimura S, Arai $\mathrm{T}$ (1993) Reference pain following percutaneous cervical cordotomy. Pain 53:205-211 